\title{
Changes in Population and Land Use Over Time in the Ecuadorian Amazon.
}

\author{
Richard E. BILSBORROW ${ }^{1}$, Alisson F. BARBIERI ${ }^{2}$, and William PAN ${ }^{3}$
}

\begin{abstract}
This paper draws upon a detailed longitudinal survey of households living on agricultural plots in the northern three provinces of the Ecuadorian Amazon, the principal region of colonization by migrants in Ecuador since the 1970s. Following the discovery of petroleum in 1967 near what has subsequently come to be the provincial capital and largest Amazonian city of Lago Agrio, oil companies built roads to lay pipelines to extract and pump oil across the Andes for export. As a result, for the past 30 years over half of both Ecuador's export earnings and government revenues have come from petroleum extracted from this region. But the roads also facilitated massive spontaneous in-migration of families from origin areas in the Ecuadorian Sierra, characterized by minifundia and rural poverty. This paper is about those migrants and their effects on the Amazonian landscape. We discuss the data collection methodology and summarize key results on settler characteristics and changes in population, land use, land ownership, technology, labor allocation, and living conditions, as well as the relationships between changes in population and changes in land use over time. The population in the study region has been growing rapidly due to both natural population growth (high fertility) and in-migration. This has led to a dramatic process of subdivision and fragmentation of plots in the 1990's, which contrasts with the consolidation of plots that has occurred in most of the mature frontier areas of the Brazilian Amazon. This fragmentation has led to important changes in land tenure and land use, deforestation, cattle raising, labor allocation, and settler welfare.
\end{abstract}

\section{KEY WORDS}

Ecuadorian Amazon; agricultural colonization; population change; land use change; migration

\section{Mudanças Populacionais e de Uso da Terra na Amazônia Ecuatoriana.}

\begin{abstract}
RESUMO
Este artigo baseia-se em uma pesquisa longitudinal sobre assentamentos agrícolas em três províncias no norte da Amazônia equatoriana, a principal região de colonização agrícola no país desde 1970. A partir da descoberta de reservas de petróleo em áreas próximas a Lago Agrio, capital provincial e maior cidade da Amazônia Equatoriana, empresas petrolíferas iniciaram a abertura de estradas e construção de oleodutos visando a extração, transporte através dos Andes e exportação de petróleo. A exploração petrolífera na Amazônia Equatoriana tem respondido, nos últimos trinta anos, por cerca da metade dos rendimentos com exportação e na arrecadação governamental. As estradas abertas na Amazônia facilitaram a imigração maciça e espontânea de famílias dos Andes equatorianos, uma região tradicionalmente caracterizada pela presença de minifúndios e pobreza rural. Este artigo discute a metodologia de coleta de dados e sumariza os principais resultados de pesquisas sobre esses imigrantes na Amazônia Equatoriana, especificamente em termos de mudanças nas características populacionais, uso e propriedade da terra, tecnologia, trabalbo e padrão de vida, assim como relações entre características populacionais e uso da terra ao longo dos anos 90 . O elevado crescimento populacional devido ao crescimento natural (alta fecundidade) e contínua imigração tem engendrado a subdivisão e fragmentação de lotes rurais desde 1990, em contraste ao processo de concentração de terra em diversas partes da Amazônia brasileira.
\end{abstract}

\section{PALAVRAS-CHAVE}

Amazônia Equatoriana; colonização agrícola; mudanças populacionais; mudanças no uso da terra; migração

${ }^{1}$ Department of Biostatistics and Carolina Population Center, University of North Carolina at Chapel Hill

${ }^{2}$ Department of City and Regional Planning and Carolina Population Center, University of North Carolina at Chapel Hill

3Johns Hopkins University 


\section{ACTA \\ AMAZONICA}

CHANGES IN POPULATION AND LAND USE

OVER TIME IN THE ECUADORIAN AMAZON

\section{INTRODUCTION}

Recent studies on the Amazon Basin have focused on deforestation and changes in land use using data from remote sensing imagery, and, to a lesser degree, household surveys. The emphasis has been, therefore, on the environmental degradation of tropical forests rather than on the living conditions, land use and demographic characteristics of the migrant settler families who are the proximate actors directly responsible for much of the degradation. This paper presents results from data on a unique panel of farm households, to assess migrant settler household demographic characteristics, land use, land ownership, technology, labor and living conditions in the Ecuadorian Amazon between 1990 and 1999. The discussion also includes a review of the dramatic changes over time in population and land use.

The Ecuadorian Amazon, one of the richest reserves of biodiversity in the world (Myers et al, 2000), has been experiencing the highest rate of deforestation of any country's Amazonian area (FAO, 2001). Most of this deforestation has been caused by the agricultural colonization that followed the discovery of oil in 1967. This deforestation has in turn probably resulted in great loss of biodiversity, though this has not yet been quantified. Furthermore, increasing urbanization, especially in the 1990s, has engendered new patterns of population mobility within the Amazon, as well as changes in the ways rural settlers make their living.

Recent transformation in the Ecuadorian Amazon frontier included (1) the decreasing sustainability of farming as a way of life, and increasing pressures on resources as a result of plot fragmentation, high population growth, and constraints on further land extensification as the frontier becomes closed; (2) expansion of the road network, improving physical accessibility to other rural areas as well as urban areas, and increasing the links between farms and towns; and (3) socioeconomic and demographic changes related to (1) and (2) as well as changes in household composition and life cycle factors.

\section{Study Area: Agricultural Settlement in the Ecuadorian Amazon}

The Ecuadorian Amazon, a region known in Ecuador as the "Oriente" (Figure 1), is located in the western Amazon rainforest. This region, the Pacific Coast lowlands, and the Highlands or Sierra represent the three distinct landscapes of the country. The Oriente is mostly sparsely populated tropical lowland rainforest, and is an area of extraordinary biodiversity, among the very highest in the world (Myers et $a l, 2000)$. The altitude in the Oriente varies from the Andean foothills to about 200 meters above sea level at the eastern border with Peru, with the study area $350 \mathrm{~m}$ to $250 \mathrm{~m}$, straddling the Equator, with annual rainfall of 3-5 m. Soil conditions are better than in most of the lower Amazon areas of Peru or Brazil, as a result of pockets of volcanic (black) soils, although soil quality is highly variable and much is poorquality red soils with high acidity and aluminum toxicity. Another difference from the Brazilian Amazon is that the Ecuadorian Amazon has a year-round growing season, with rain occurring in all 12 months. This requires the use of slash and mulch clearing practices (cutting trees and leaving them to decompose), with little burning of trees or agricultural residues. Nevertheless, by the turn of the millennium there appears evidence of micro-climatic changes in some areas, perhaps due to the loss of vegetation, resulting in drier conditions in certain months and making possible burning sometimes. Also in Ecuador, unlike Brazil, large-scale commercial agriculture, ranching and logging have never played major roles, with most forest cleaning occurring at the hands of small farmers. This provides a better scenario for examining the roles of demographic factors relative to others in land use/land cover (LULC) change.

From the mid-1970's to the present, the region has thus become increasingly occupied by agricultural settlers, and continues to be seen by some as an "open frontier", attracting migrants from other parts of Ecuador, especially the Sierra which is characterized by rural poverty, extremely concentrated landholdings, and "minifundia". As a consequence of the colonization process and oil extraction activities, especially the establishment of a network of roads by the oil companies, the study region has witnessed high rates of deforestation, with forest cover on sample farms falling from essentially $100 \%$ in 1970 to $59 \%$ by 1990 and $45 \%$ in 1999 .

The study area in the Northern Amazon began to be occupied by agricultural settler families after the discovery of oil in 1967. This was followed by the laying of pipelines and a road network for the exploitation of oil, and by the establishment of the new town of Lago Agrio next to the first oil camp of Texaco. Petroleum has since provided over half of the value of Ecuador's export revenues and also over half of government revenues (from royalties) virtually every year since the early 1970's. There are now four main towns in the study area: Lago Agrio or Nueva Loja (the largest, with 34,000 people, according to the 2001 census), Francisco de Orrellana or Coca, Joya de los Sachas and Sushufindi. The total population in the Ecuadorian Amazon in 1990 was 384,582 - $4 \%$ of the Ecuadorian population (INEC 1992). The population in 2001 reached about 546,602 , or $5 \%$ of the total, following 30\% growth in 1990-1999 compared to $22 \%$ in the country as a whole (INEC, 2001). The especially high growth rate of the Amazon population results from fertility being higher than elsewhere in the county and from continuing inmigration. Thus the total fertility rate, TFR (number of births a woman will have during her lifetime, if current age-specific rates continue to prevail until she reaches the end of her reproductive age at 50) in the Amazon was probably over 7 prior to 1990 and still 5.5 in 2000, compared to 3.4 for the country as a whole in 2000 (CEPAR, 2000). Migrants continue to move to the Amazon from the Sierra and Coast (and recently from Colombia, including several thousand refugees). 


\section{ACTA AMAZONICA}

Virtually all colonization in the Ecuadorian Amazon has been spontaneous, facilitated by the opening of roads by oil companies, which greatly improved physical accessibility. For ultimate drivers, however, one has to examine what it is that leads the large numbers of spontaneous migrants to leave their places of origin. Though this has not been quantitatively demonstrated, it seems likely that the lack of land and rural poverty, linked directly to the extreme concentration of landholdings, must be major factors in impelling out-migration.

Most colonists are poor and arrived without capital to invest in their plots. They also faced a lack of infrastructure or governmental assistance, in contrast to some of the early colonists in the Brazilian Amazon (e.g., northern Mato Grosso, and Machadinho, in the state of Rondônia). Moreover, in Brazil the widespread availability of land has made possible the use of very extensive land use practices, also stimulated by the poor soils. This has led to high land turnover and increasing concentration of landholdings - with small farmers' land increasingly loosing fertility and being bought up and consolidated by cattle ranchers and loggers. In contrast, in Ecuador Amazon soils vary in fertility,

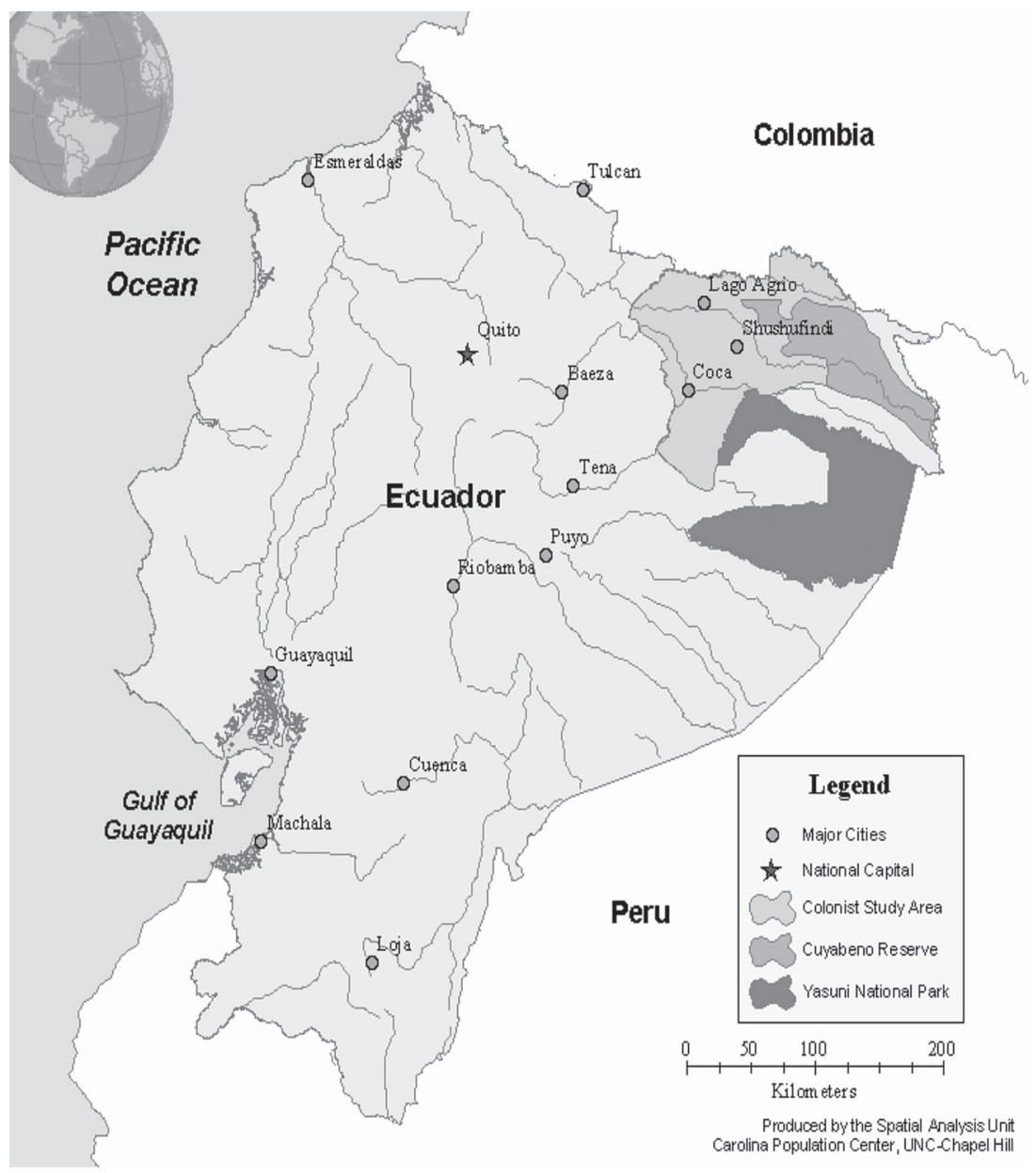

Figure 1 - Study Area in the Northern Ecuadorian Amazon some being of volcanic origin and high fertility, and land in the Amazon is no longer plentiful relative to population. Indeed, due to rising population pressures on the land, the Amazon region of Ecuador is experiencing land subdivision and intensification, as we will see below.

One final important contrast with the Brazilian Amazon is the urbanization process. According to the 2000 Brazilian census, the Brazilian Amazon has two cities with more than a million inhabitants (Belém and Manaus) and ten more cities with over 100,000 people. And of the 12 million inhabitants in the Brazilian Amazon in 2000 ( $7 \%$ of the total Brazilian population), $69.4 \%$ were living in urban areas. In Ecuador in contrast, the largest city in the Amazon, Lago Agrio, had only 34,000 inhabitants in 2001 at the time of the last census, and the urbanization level was only $36 \%$, though considerably higher than the $26 \%$ level of 1990 (INEC, 1992, 2001). The high population growth rates due to both high fertility and the continuing influx of migrants, and the expectation of further expansion of the oil industry (recent discoveries of large new deposits and the completion of a second trans-Andean oil pipeline in late 2003) suggest that urbanization will play an increasingly important role in the spatial reconfiguration of the Ecuadorian Amazon. As we shall see below, findings from the 1990-1999 longitudinal survey also support this conjecture, documenting high population growth and increasing subdivision of farms. The rural population is also increasingly employed in off-farm work, pointing to the growing importance of urban labor markets. A community-level survey carried out in 2000, linked to the 1999 NASA household survey, revealed high population growth rates of many rural communities, as they acquire urban characteristics and infrastructure.

\section{Data: The Longitudinal Household Survey, 1990 and 1999}

Our research on population and land use in the northern Ecuadorian Amazon began in 1989 and focused on the effects of large-scale colonization on agricultural land use and livelihoods and on deforestation. The initial study was developed by Richard Bilsborrow and Francisco Pichón, and served as the basis for the Ph.D. dissertations of Pichón and others and various publications (e.g., Pichón, 1993, 1997; Pichón \& Bilsborrow, 1999; Murphy et 


\section{ACTA \\ AMAZONICA}

CHANGES IN POPULATION AND LAND USE OVER TIME IN THE ECUADORIAN AMAZON al, 1997; Marquette, 1998). At that time there was no thought of collecting data longitudinally; indeed, reviewers at the U.S. National Science Foundation did not believe it was even possible to design and conduct a survey of households in the Amazon.

A key step in designing a good survey is having an adequate sample frame. We were able to use a sample frame based on data on the agricultural plots settled in the region provided by the government land reform and colonization agency, IERAC (Instituto Ecuatoriano de Reforma Agraria y Colonización), which had been much more active in the Amazon region than elsewhere in the country. The sample frame at IERAC consisted of a large map listing each of the areas opened to settler occupation, called "sectores" (sectors), together with the number of plots originally allowed for settlement in each sector.

Agricultural plots for the survey were selected with a two-stage sampling strategy. In the first stage we selected sectors from the IERAC list using systematic sampling, and in the second stage we selected a number of (contiguous, for ease of fieldwork) "fincas" or agricultural plots of about 50 hectares each from each sample sector selected in stage 1. Both sectors and number of fincas in each sector were sampled using PPS (probabilities proportional to size), making the sample a self-weighting sample and thereby virtually obviating the need to weight the data for any analysis comprising fincas (farms). IERAC required the settlers of the fincas of each sector to form a cooperative organization called "precooperativa" to get IERAC to survey their borders to establish finca boundaries and to be eligible to subsequently seek land titles. The two-stage sampling procedure led to a sample of 64 sectors (from the nearly 300 in the region), sample "takes" of 5 to 10 fincas randomly selected from each of the sample sectors, based on the size of the sector, and a total of 480 fincas. This sample was thereby selected to be representative (accounting for 5.9\%) of the entire rural settler population of the study region in 1990 , such that the results can be taken to be representative of that population. This contrasts with many surveys of migrant settlers in Brazil and elsewhere, which have been based on limited samples along a road or quota samples.

The collaboration of the respondents with the Ecuadorian interviewers was extraordinary, leading to a refusal rate of only $3 \%$. This plus the lack of habitation or of economic activity on some fincas resulted in a final sample of 408 plots with 418 completed household interviews in 1990. Figure 2 shows the location of sample sectors selected in the study area.

Subsequent to this first, baseline survey, many changes have occurred in the study area and in Ecuador in general during the 1990s. To understand the implications of these changes for land use in the study region, we undertook a follow-up survey in 1999, revisiting the same plots of land or fincas as were visited in 1990 (the new project was funded primarily by NASA, as part of the LBA program, which focused on Brazil). The second round of data collection also involved processing and analyzing satellite imagery, air photography, and topographic and road maps; using global positioning system (GPS) devices to record locations of all farm plots and dwellings, as well as of roads, towns and infrastructure throughout the study region; and groundtruthing of land use by farmers using GPS.

The result is a panel survey of plots of land, not of households per se (though over half the household heads were the same in 1999 as in 1990), involving interviewing all households found on the original sample fincas.

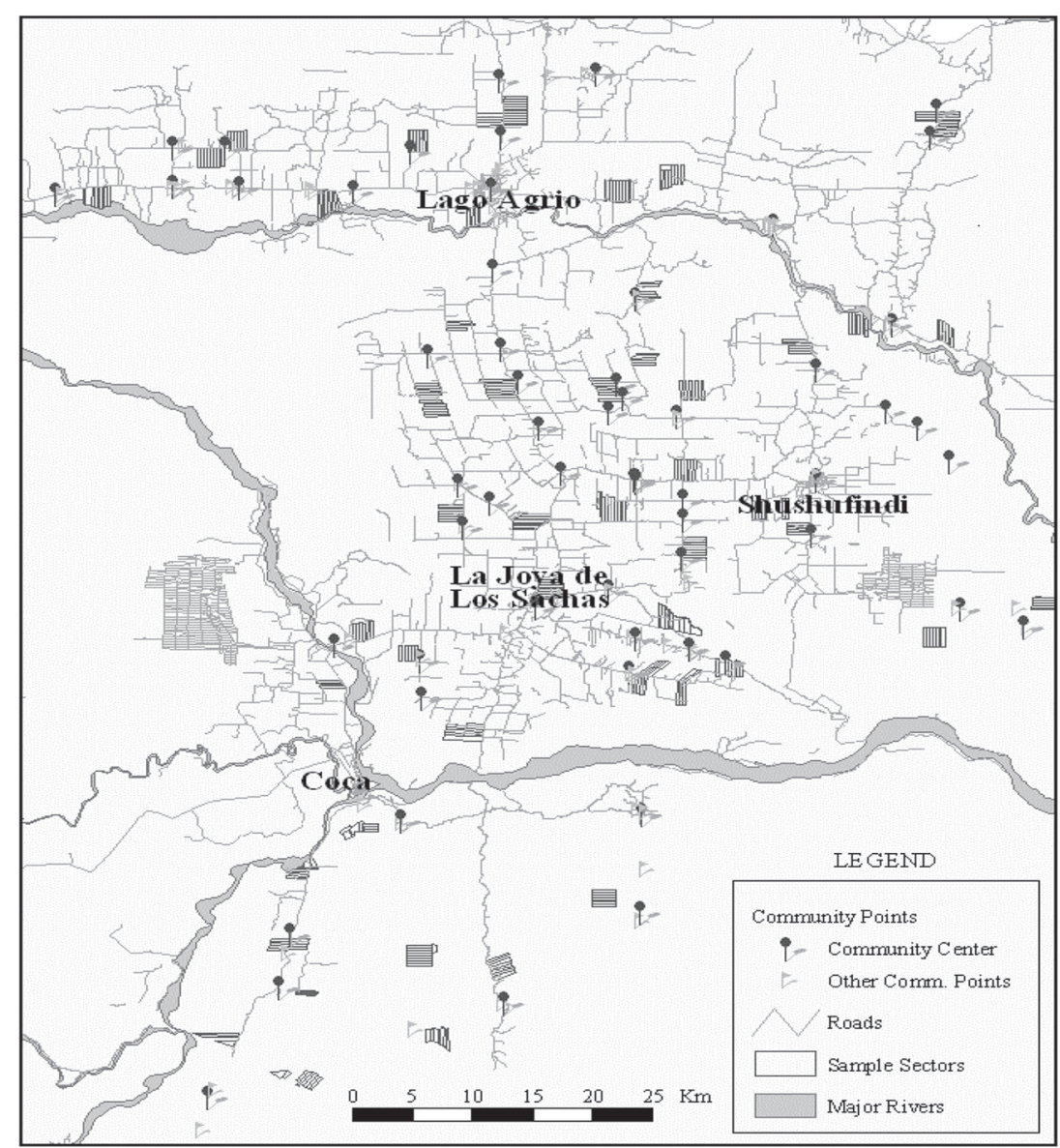

Figure 2 - Sample Households and Sectors in the Northern Ecuadorian Amazon 


\section{ACTA \\ AMAZONICA}

CHANGES IN POPULATION AND LAND USE OVER TIME IN THE ECUADORIAN AMAZON
Surprisingly, far more households were found to be living on the plots than in 1990, as a result extensive subdivision of plots. Thus many of the 1990 owners of fincas (about $40 \%)$ subdivided them by 1999 , giving parts to children reaching adulthood or selling portions to migrants coming into the region, to meet economic needs. The process of devolution to children is evidently linked closely to previous high fertility of settlers. Both forms of subdivision reflect an accommodation to increasing population pressures on land in the region, where the agricultural frontier has been largely closed by the creation of two large national parks and the adjudication of communal land titles to large areas of land to indigenous population groups, the latter mainly in 1991.

The 1999 household survey also documented that, besides the new subdivisions created for farm activities, many other, smaller subdivisions (called "solares", having less than a hectare) also occurred, along roads and near towns. Virtually all of the latter subdivisions are for residences. The final result is that nearly 950 questionnaires had to be administered to heads of household and a similar number to their spouses found to be living on the original fincas, taking into account all the new subdivisions that occurred by 1999. The final completed sample comprises 767 fincas of 708 independently managed farm owners (648 owners have one farm plot, 56 owners have two, and three have three farms), plus 111 households living on solares. There are also 652 completed survey questionnaires from the spouse.

\section{RESULTS}

\subsection{Land Use Change Over the Period 1990 to 1999}

One of the most remarkable features of land use change in the Ecuadorian Amazon during the 1990's is the striking pattern of household formation and land subdivision. Of the total of 886 farms found on the original fincas in 1999, only $30.6 \%$ represent intact farms, that is, were the same finca originally sampled in 1990 , with no subdivision. The remaining $69.4 \%$ were farms created by subdividing an original finca or finca madre ("mother finca") since 1990. The rise in the number of subdivisions is most intense in the later years of the decade, suggesting a process may be underway of much further parcelization of fincas in the future. Thus, beginning in 1990 when only 5\% of the fincas were subdivisions, it took seven years (to the end of 1997) for about half (51\%) of the total fincas in the 1999 survey to be created as new subdivisions. Less than a year and a half latter, by the time of the survey, this percentage reached $68.5 \%$.

Table 1 compares a number of household characteristics and land use of the two groups of farm owners interviewed in 1999 - those who first became owners of fincas since 1990, who may be referred to as short-term owners; and those who had already been heads of household in 1990, or long-term owners. As can be seen in the table, short term owners are much less likely to have either an intact (vs. subdivided) farm or a title to their farm, and also have plots only about half the size of those of nuclear households (even though some new owners have bought up intact original fincas). Due to the absence of a secure land title, the new owners are also much less likely to have received a loan. They are slightly more likely to have been born in the Amazon, some in fact being sons born, in the study area, of parents who arrived in the 1970's among the early settlers. Post-1990 owners, who tend to have smaller farms, also engage in more intensive land use practices, with larger proportions of their plots cleared, and higher shares in annual and perennial crops and less in pasture.

Directly related to their having smaller plots, short-term owners are more likely to have one or more household members working off-farm (about 3/4 of this is agricultural labor) and less likely to hire laborers to work on their own farm. However, both of these differences are smaller than we expected, given the large differences in landholding sizes of

Table 1 - Household and Land Use Characteristics: Comparison of Long Term and Short Term Owners in the Northern Ecuadorian Amazon, 1990 and 1999a

\begin{tabular}{lcc}
\hline \hline \multicolumn{1}{c}{ Characteristics } & $\begin{array}{c}\text { Long Term Short Term } \\
\text { Owners }\end{array}$ & Owners \\
\hline Household Demographics & & \\
\hline $\begin{array}{l}\text { Number of households } \\
\text { Head of household born in the } \\
\text { study area }\end{array}$ & 315 & 393 \\
$\begin{array}{l}\text { Engage in off-farm employment } \\
\text { Hire day laborers }\end{array}$ & $49 \%$ & $12 \%$ \\
\hline Land Tenure & $48 \%$ & $40 \%$ \\
\hline $\begin{array}{l}\text { Intact farm (no subdivisions) } \\
\text { Hold full legal title }\end{array}$ & $40 \%$ & $21 \%$ \\
Hold certificate of possession & $53 \%$ & $21 \%$ \\
Received credit in Amazon & $34 \%$ & $16 \%$ \\
\hline
\end{tabular}

Assets

Own cattle (one or more head) $\quad 59 \% \quad 31 \%$

\section{Land Use}

\begin{tabular}{lcc}
\hline Mean Plot Size (ha) & 34.2 & 18.4 \\
$\%$ in Forest & $42 \%$ & $36 \%$ \\
$\%$ in Pasture & $30 \%$ & $23 \%$ \\
$\%$ in Perennial Crops & $21 \%$ & $27 \%$ \\
$\%$ in Annual Crops & $7 \%$ & $14 \%$ \\
\hline \hline
\end{tabular}

a : $N=708$. M any farmers owned two or more plots in the sample, resulting in 708 independent farm owners. Whenever one farmer owned more than one plot in the sample, those plots were aggregated to create one unit of observation (that is, a farmer with two plots of 30 ha and 50 ha in the sample is recorded as a single observation with $80 \mathrm{ha}$ ). The resulting total number of farm owners is 708 . 


\section{ACTA \\ AMAZONICA}

CHANGES IN POPULATION AND LAND USE

OVER TIME IN THE ECUADORIAN AMAZON the two groups. This indicates widespread, complex household labor allocation strategies, with many households with large plots both having one or more household members working off the farm for some months of the year (often on other farms in the same sector) while also hiring in wage laborers at times of their own peak labor needs or for clearing forest. It should also be noted that the families living on small house plots called solares, not included in Table 1 (111 families with completed questionnaires) also provide an additional pool of labor for farm settler land owners to draw upon.

Table 2 shows the distribution of plot sizes of colonists in 1990 and 1999. One can see a dramatic process of land fragmentation occurred in the region during this time interval, due to extensive subdivision, as discussed above. This is one of the most striking changes in the study area during the 1990 's, and is directly linked to the considerable population increase. Heads of households subdivide their plots for various reasons, including selling portions for cash, giving away part as an early inheritance for children, lending parcels to recently in-migrated family members looking for land (brothers, cousins, etc.), and (but rarely) renting out parcels to seek rent income. The increase in the number of subdivisions thus results from both recent in-migration and past high fertility, the latter affecting the number of bequests to children as they reach adulthood and want their own plots. But the major factor in the vast increase in subdivisions continues to be sales to new in-migrants.

One implication of this changing pattern of plot sizes is the average quality of soil reported by a household head. Edaphic factors such as soil quality and topography should be the same in 1990 and 1999 (since the plots are the same). However, differences can be found since subdivisions appear concentrated on areas with good soils and flat land. Thus the proportion of heads reporting to have black/fertile soil rose from $44 \%$ to $58 \%$, while those reporting hilly land fell from $31 \%$ to $10 \%$. In both years, most farmers also reported soil quality declining over time.

Table 2 - Plot Sizes of Settlers, Northern Ecuadorian Amazon, 1990 and 1999

\begin{tabular}{lcccc}
\hline \hline \multirow{2}{*}{ Size $(\mathrm{Ha})$} & \multicolumn{2}{c}{$1990(\mathrm{~N}=416)$} & \multicolumn{2}{c}{$1999(\mathrm{~N}=706)$} \\
\cline { 2 - 5 } & $\mathrm{N}$ & $\%$ & $\mathrm{~N}$ & $\%$ \\
\hline 2 & 1 & 0.2 & 37 & 5 \\
$2-4.9$ & 8 & 2 & 123 & 17 \\
$5-9.9$ & 8 & 2 & 96 & 14 \\
$10 \tilde{N} 19.9$ & 20 & 5 & 85 & 12 \\
$20-29.9$ & 34 & 8 & 70 & 10 \\
$30-39.9$ & 52 & 13 & 67 & 10 \\
$40-49.9$ & 118 & 28 & 120 & 17 \\
$50-59.9$ & 135 & 33 & 75 & 11 \\
$60-89.9$ & 20 & 5 & 22 & 3 \\
$>90$ & 20 & 5 & 11 & 2 \\
Mean plot size & 46.5 & & 25.5 & \\
\hline \hline
\end{tabular}

Figure 3 illustrates patterns of land use in 1990 and 1999 , especially the process of continuing extensification of agriculture over time on sample plots, with the cultivated area increasing at the expense of forest cover. In 1990, an average plot was 46 hectares, with 27 ha $(59 \%)$ in forest, 6 ha $(13 \%)$ in perennials, 8 ha $(18 \%)$ in pasture, 2 ha $(4 \%)$ in annual crops, and the remaining 3 ha in fallow or swamp. By 1999, the average plot (with far more variation) was about half the size as in 1990 , only 25 ha, and had only 11 ha ( 45 $\%)$ left in forest, 5 ha (20\%) in pasture, 3.3 ha (13\%) in perennial crops, 1.5 ha (6\%) in annual crops, 2.8 ha in fallow, and 1 ha in swamp. Forest cover declined at an annual rate of $3 \%$ on settler farms, but without other dramatic changes in land use. Thus perennials (largely coffee) are only slightly less prevalent in 1999 , with $82 \%$ of farms growing coffee in versus $95 \%$ in 1990. This decline is doubtless due in part to coffee prices dropping in the 1990s. It is probable that this decline will continue as more and more farmers destroy old coffee plants planted in the $1970 \mathrm{~s}$ and $1980 \mathrm{~s}$ as they reach the end of their productive lives.

Most farms grow annual crops for family consumption and not for market sale, so the area in annual crops is small, and fell only slightly as families continued to produce annuals as subsistence crops. Within annual crops, a decline occurred in the percentage of settler farmers raising corn from $45 \%$ in 1990 to $22 \%$ in 1999 , while rice cultivation rose, but from a low base. The increase in rice was partly due to the activities of probably the most successful development-oriented NGO working in the region, FEPP (Fundación Ecuatoriana para Progreso Populorum), which promoted new dwarf varieties developed by the Ecuadorian agricultural research station (known as INIAP-Payamino: Instituto Nacional para Investigaciones Agropecuarias, located on the Rio Payamino, just north of Coca).

Pasture land remained about the same between the two years as a percentage of the total, though the absolute area in pasture declined significantly overall, almost by half. Table 3 below shows that the mean number of cattle declined, even
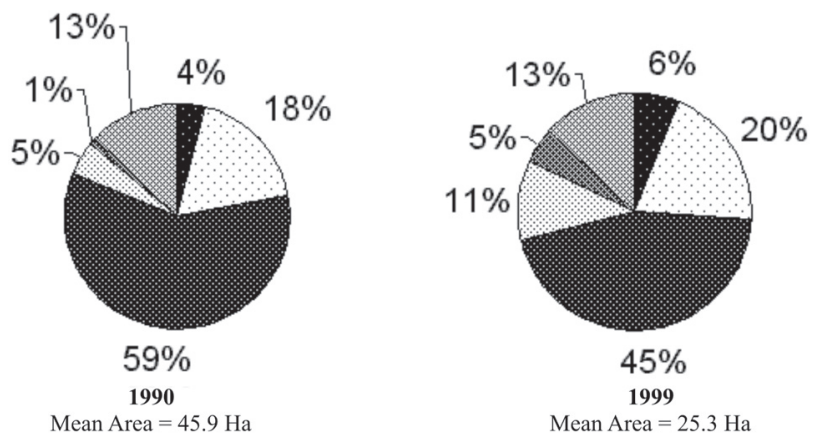

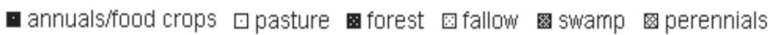

Figure 3 - Land Use Distribution in Colonization Areas of the Northern Ecuadorian Amazon, 1990 and 1999 


\section{ACTA AMAZONICA}

though the mean number of head in each of the five land size strata (except for those over $50 \mathrm{ha}$ ) did not change significantly. It is thus the change in the distribution of farms across the land size strata, due to subdivision, that accounts for the change in the mean number. It is also clear that the one-to-one relationship observed in 1990 between hectares of pasture and head of cattle weakened by 1999, with there now being more pasture per head. While this could result from degradation in the mean quality of pasture land over time, it may also be that farmers were keeping more land temporarily in pasture, hoping to add more cattle in the future.

The decline in cattle ownership in the Ecuadorian Amazon study region contrasts with what has been observed elsewhere in Latin America, where pasture areas have risen substantially over time in settlement areas along the agricultural frontier (e.g., DeWalt, 1985; Bilsborrow \& Carr, 2001; Hecht, 1985). This also had been the trend in Ecuador as well prior to 1990 (Pichón, 1993). Cattle, as farmers report, are a desirable, multi-purpose asset that provides milk for children, cash income from the sale of the animal, and meanwhile a form of savings (on the hoof); sometimes cattle can also serve as collateral to secure a loan. But the usual cattle expansion over time has been halted in Ecuador, due to the process of finca fragmentation that made many farms too small by 1999 to support extensive forms of land use such as cattle raising. Thus Table 3 shows that $57 \%$ of the farms owned cattle in 1990, with a mean number of 12 head, whereas by 1999 only $41 \%$ of the farms had any cattle, with a mean of only 7 head. The total number of cattle on all sample plots together fell from about 2800 in 1990 to 2100 in 1999 , evidently due mainly to the dramatic change in the composition (size distribution) of farms.

Figure 3 also shows that land in fallow appeared to increase substantially between the two years, which could indicate that more of the land is losing its soil fertility and being left fallow to regenerate. This would be interesting in and of itself, and calls for further study, though the area is still very small, and moreover some of the increase is only apparent, as questions about fallow land in 1999 were more detailed than in 1990. In the first survey, farmers were only asked to indicate how much land they had in fallow (or in "rastrojo"), whether for future use or regeneration. In 1999 respondents were informed that the project was interested in accurate information about all fallow land, and asked the farmer to provide separate estimates of his areas in fallow according to the years since last use, in four categories: less than 2, 2-6, 7-11, and 12 or more, with the latter two considered secondary forest. Farmers were also asked to indicate on a sketch map areas in fallow, to explain why areas were in fallow (for those fallow $7+$ years), and if they intended to use the land again, after how many years and for what purpose.

The results above suggest that the process of deforestation has continued in the Ecuadorian Amazon, not for the usual reason seen elsewhere in most of Latin America (including in the Brazilian Amazon) in which landholdings change hands from relatively intensive forms of land use such as raising annual and perennial crops-mostly by small farmers, who initially clear the land-to extensive forms of land use, such as cattle raising on large farms created through consolidation of small farms. The trend towards cattle raising and any possible beginning of consolidation of plots in Ecuador has been halted, as a result of the rapid growth of population in the region and the associated fragmentation of farm plots. This has reduced the sizes of many farms so much as to make extensive forms of land use impractical for producing sufficient income to support a family.

Other important changes between 1990 and 1999 related to land use in the study region pertain to land tenure, labor, technical assistance, and credit. Table 4 shows a dramatic reduction in the proportion of farm household heads with a full land title between 1990 and 1999: in 1990, $50 \%$ of migrant farmers had a full legal title ("escritura") another 43 \% had a "certificado de posesión" (provisional land title, both types adjudicated by IERAC); by 1999 these figure fell to $34 \%$ and $12 \%$, respectively. At the same time, the percentage of households with no title at all rose from 7 to 49. Having a provisional land title provides considerable security of land tenure but does not legally allow resale, nor provide collateral for loans (both of which require an escritura, or legal document showing ownership of the land). In fact, the lack of a full legal title has not affected resale.

Table 3 - Cattle and Pasture Land by Plot Size, Northern Ecuadorian Amazon, 1990 and 1999

\begin{tabular}{|c|c|c|c|c|c|c|c|c|}
\hline \multirow[b]{2}{*}{ Plot Size (Ha) } & \multicolumn{4}{|c|}{1990} & \multicolumn{4}{|c|}{1999} \\
\hline & $\mathbf{N}$ & Own Cattle & $\begin{array}{c}\text { Mean No. } \\
\text { Head }\end{array}$ & $\begin{array}{l}\text { Mean Ha } \\
\text { Pasture a }\end{array}$ & $\mathbf{N}$ & Own Cattle & $\begin{array}{c}\text { Mean No. } \\
\text { Head }\end{array}$ & $\begin{array}{l}\text { Mean } \mathrm{Ha} \\
\text { Pasture a }\end{array}$ \\
\hline$<10$ & 17 & 3 & 1.6 & 0.6 & 297 & 60 & 2.5 & 1.5 \\
\hline $10-19.9$ & 20 & 8 & 3.3 & 3.8 & 89 & 39 & 3.8 & 6.4 \\
\hline $20-29.9$ & 34 & 16 & 6.5 & 5.8 & 79 & 35 & 4.4 & 9.2 \\
\hline $30-49.9$ & 172 & 103 & 8.3 & 9.8 & 201 & 121 & 8.7 & 13.8 \\
\hline$>50$ & 170 & 106 & 17 & 16.6 & 99 & 56 & 10.5 & 19 \\
\hline Total & 413 & 236 & 11.9 & 12.3 & 765 & 311 & 6.8 & 10.9 \\
\hline
\end{tabular}

a : among farms owning cattle 


\section{ACTA \\ AMAZONICA}

CHANGES IN POPULATION AND LAND USE

OVER TIME IN THE ECUADORIAN AMAZON
There are two reasons for the dramatic decline in the percentage of migrant settlers with land titles. One is that the Ecuadorian government agency in charge of land titling, IERAC, which had existed since the original agrarian reform law was passed in 1964 and which had been especially active in land titling in the Amazon region, was terminated in 1993 by the neo-liberal government. It was replaced by a weak agency, INDA, which has done little in the way of granting land titles. Since then the little land titling that has taken place in the region was mostly carried out by a small NGO called FEPP, through a subcontract from INDA, but only in a small number of communities. The second reason titling has declined so much is that farmers are rapidly selling off or giving in inheritance small plots as the subdivision of lands proceeds in the region. Many of these transactions are intrafamily and probably not viewed as requiring legitimization through formal titles, which cost money. Such subdivisions, whether involving an exchange among kin or friends or sale to a new in-migrant, carry implicit de facto contracts and rights of use.

In 1990, just over half of the colonists interviewed had purchased their plots from another settler, while the rest were the original settlers, and had acquired their farms and titles from IERAC. Data from the 1999 survey indicate that over half (52\%) of the heads of farm households had acquired their farms by buying them from another colonist or bank, $24 \%$ had inherited them (vs. virtually none in 1990), $13 \%$ were renting (vs. $5 \%$ in 1990), and the remainder were mostly squatting on or occupying the plot. Less than $2 \%$ of the farms acquired between 1990 and 1999 had land titles adjudicated by the government, most by IERAC in 1990-93 before its termination.

Table 5 shows a substantial decrease from $60 \%$ to $41 \%$ in farms hiring outside labor (though the absolute number hiring increased slightly), while at the same time the percentage of households with one or more members engaged in off farm work increased by half, from 35 to 51 . Earlier work based on the 1990 data found off-farm work to be negatively affected by plot size and positively related to the education of the person and the household head's consumption aspirations (Murphy et al, 1997).

In addition to farm households (the focus of the present paper), 111 non-farm residential households (solares) found on sample fincas in 1999 were interviewed, with virtually all (95\%) reporting off-farm employment. This reflects a significant change in the agricultural labor supply in the region since 1990 , when many farmers in conversation bemoaned the labor shortage in the region. The labor pool is also larger due to the rapid growth of urban areas, the larger ones of which have a growing pool of floating migrant workers seeking work (the growth of these areas in the 1990s, and of their population and infrastructure, is documented in data collected in a community-level survey in the study region in 2000 (Vallejo \& Bilsborrow, 2001). With the fragmentation of fincas, there has been a significant shift from a situation in which most fincas hired labor to work on essentially intact fincas up to 1990 to a much more complex labor situation in 1999, in which many large, intact fincas continue to hire in labor, but an increasing number of households with small plots are sources of labor, selling household labor via offfarm employment. The latter undoubtedly results from the fragmentation of fincas in the 1990s, which has created two distinct types of farms, those which are mainly buyers of labor and those which are sellers of labor.

Another change affecting the landscape, and also due to radical cuts in public programs since the change in government in 1992 (even education and health were cut to half their previous shares of public expenditures), is the reduction in technical assistance. Table 5 shows that in $1990,32 \%$ of households reported having ever received technical assistance, but by 1999 this was only 19\%. Taking into account the fact that over a third of the 1990 households had left by 1999 (who may have received assistance in earlier years), and that technical assistance includes a wide range of forms of assistance going well beyond agricultural assistance only, the small increase in the absolute number receiving any type of assistance by 1999 indicates a lack of agricultural extension activities in the region (this also due to general government cuts in agricultural programs).

On the other hand, it is clear that bank credit continued to be available and even to expand, with $18 \%$ of the now much larger sample of farm owners reporting having received one or more loans between arriving in the Amazon and the time of the survey in 1999, mostly from the government development bank (Banco Nacional de Fomento). Survey responses indicate that about half of these borrowers had not repaid their loans by 1999 (and some are hoping for their debts to be forgiven, which has happened before). Loans are usually available only to farmers with full land titles, and have been used mainly to purchase cattle and/or hire laborers to clear forest to create additional pasture. Therefore, the provision of loans to farm settlers is probably directly related to deforestation and 


\section{ACTA AMAZONICA}

Table 5 - Labor, Technical Assistance and Credit on Migrant Settler Farms, Northern Ecuadorian Amazon, 1990 and 1999

\begin{tabular}{lcccc}
\hline \hline & \multicolumn{2}{c}{1990} & \multicolumn{2}{c}{1999} \\
\cline { 2 - 5 } & $\mathbf{N}$ & $\%$ & $\mathbf{N}$ & $\%$ \\
\hline Hired Labor & 243 & 60 & 315 & 41 \\
Off-farm employment & 143 & 35 & 390 & 51 \\
Received Technical Assistance & 135 & 32 & 146 & 19 \\
Received Credit & & & 172 & 22 \\
& 78 & 18 & 136 & $18 \mathrm{a}$ \\
\hline
\end{tabular}

a: Farmers reporting receiving new loans in 1990-1999.

increasing land in pasture. At the same time, the loans may have a second effect in the same direction, as the extent of indebtedness may make farmers feel pressured by debt to work the land harder to pay off the debt, leading to less land in forest and more land in pasture and/or cash crops.

An important question is how well-off, economically, are settlers, and are they better-off than in 1990 , or than they were in their places of origin. While these issues are being dealt with in a separate research paper in process, a preliminary indication is possible from data on the ownership of assets. Table 6 compares information on ownership of assets by settler farm households in 1990 and 1999. It is clear that there has been a remarkable increase in the proportion of households with electricity between the two years $(14.5 \%$ in 1990 against $37.6 \%$ in 1999). The close proportions between having electricity and having a TV (and refrigerator, to a lesser extent) in both years suggest that this last is nearly universal for households with electricity. This may also mean the settlers' health conditions have improved, since refrigerators are so useful for storing and preserving food. Households with electricity are usually also near the roads crossing the region or to towns, and inhabitants of these households are more prone to engage in off-farm work in the towns or other rural areas and may be more inclined to purchase consumer good than those living farther away, even if on larger farms. The main surprise in Table 6 is the decrease in the proportion of households with any form of radio, perhaps due to more having televisions and to effect of increasing availability of electricity replacing the use of assets such as radios that use batteries in many households. The information on gas ovens and stoves suggests that the increase in population and household formation since 1990 has created an even higher demand for fuel wood in rural areas of the northern Amazon. Finally, the proportion of households with chainsaws is slightly smaller (thought the absolute number of rural families with chainsaws has increased, given the population increase), while the proportion with vehicles doubled, but from a low level. The latter is linked to increased road access and quality, and perhaps to increasing household incomes of some farmers (to be examined in the other paper cited, in process).
All along agricultural frontiers in the developing world farmers supplement their incomes with (legal or illegal) extraction of forest products, mainly wood. In the northern Amazon this activity increased significantly between 1990 and 1999. The proportion of households engaging in wood extraction rose from 7.2 to 36.1 between the benchmark years. This has occurred despite the decline in high quality species over time from the extraction and the fragmentation of plots. Thus the proportion of plots under 20 hectares rose from 0.089 in 1990 to 0.483 by 1999 . Smaller plots are far less likely to have enough forest to facilitate wood extraction.

One last remarkable change between 1990 and 1999 is the substantial increase in the accessibility of settler farms to roads and markets. Since previous research in Ecuador (Rudel, 1983; Southgate et al, 1991) and elsewhere (e.g., Almeida, 1990 on Brazil, Heckandon, 1983 on Panama, and Kaimowitz, 1997 on Bolivia) has found road access a dominant factor in land clearing, it is expected that this change will have contributed to the increasing deforestation observed in the study region since 1990. Road infrastructure has improved as a result of both some expansion and paving of primary roads and the construction or expansion of secondary roads. Thus while in 1990 only $45 \%$ of sample farms reported having direct access to a primary or secondary road, by 1999 this had risen to $63 \%$. Some of this increase was due to the fact that subdivisions of farms created during the 1990's tended to be concentrated on farms along roads. But some expansion of roads did occur, as is seen by the fact that in 1999, 51\% of household heads reported there had been some construction or improvement of roads near their houses since 1990, improving road access for many. Table 7 provides data showing the improved road access, comparing distances from settler farms to roads and markets in the two years. According to each of the four measures in the table, distances decreased considerably, especially the most important distance measure, walking distance to the nearest road: Thus while the distance one must travel along a road served by buses is a modest obstacle to taking one's crops to market for sale or to purchase food, travel by foot over oftenmuddy paths is a far greater obstacle.

\subsection{Demographic Changes in Settler Households}

Following the dramatic patterns of land subdivision due to both new household formation and continuing inmigration, the study area in the northern Amazon has experienced significant change in population characteristics. Table 8 provides comparative demographic data for the study site in 1990 and 1999. Data refer to farm households, defined as separately managed agricultural units or 


\section{ACTA \\ AMAZONICA}

CHANGES IN POPULATION AND LAND USE

OVER TIME IN THE ECUADORIAN AMAZON subdivisions with over 0.5 ha of land; solares are excluded since they reflect a type of household distinct from those surveyed in 1990 (they are non-farm households who support themselves by off-farm work). In 1990, the average farm household size was 6.6, and the population was typically young as befits a population living along the agricultural frontier, with $41 \%$ below 13 years of age. The dependency ratio $(0.79)$ suggests a high fertility regime prior to 1990 , and the age composition indicates a modest working age population relative to the high number of child dependents (and a small proportion of older persons). The dependency ratio in 1999 is almost the same, showing little change in the worker-dependent proportions, but the average household size is smaller - 5.9. Thus even if a dramatic decline in fertility occurs in the near future, population momentum, the current age distribution with a large proportion of young women ensures that the number of births will continue to be high and therefore that natural population growth (difference between fertility and mortality of the population, excluding the effects of migration) will be high for some years to come.

The mean age of the head and spouse shows little variation between 1990 and 1999, reflecting (Bilsborrow, 2002) the fact that the effect of the aging by nine years of the (majority of) the 1990 heads who remained on their farms is compensated by the change in the composition of household heads. In 1999 the latter also includes the sons of 1990 heads becoming themselves new heads of

Table 6 - Comparison of Assets Owned by Settler Families, Northern Ecuadorian Amazon, 1990 and 1999

\begin{tabular}{lcc}
\hline \hline \multirow{2}{*}{ Asset } & $1990(\mathrm{~N}=401)$ & $1999(\mathrm{~N}=654)$ \\
\cline { 2 - 3 } & $\%$ & $\%$ \\
\hline TV & 12.72 & 36.09 \\
Radio a & 61.60 & 36.70 \\
Gas Oven / Stove & 15.21 & 11.62 \\
Stove (Wood) & 51.52 & 71.56 \\
Refrigerator & 9.98 & 27.76 \\
Chainsaw & 30.67 & 23.39 \\
Vehicle (pickup, car, & 4.24 & 8.10 \\
motorized boat) & 14.46 & 37.61 \\
Electricity & .
\end{tabular}

a : Simple radio (using batteries), radio-cassete player or sound system

Table 7 - Location of Migrant Settler Plot: Comparison of Distances, Northern Ecuadorian Amazon, 1990 and 1999

\begin{tabular}{lcccc}
\hline \hline & \multicolumn{2}{c}{$\begin{array}{c}1990 \\
\end{array}$} & $\begin{array}{c}1999 \\
(\mathbf{N}=418 \text { HHs })\end{array}$ & $(\mathbf{N}=765$ HHs $)$ \\
\hline Average Total Distance to Market $(\mathrm{Km})$ & 28.2 & \multicolumn{2}{c}{20.4} \\
Road Distance to Market $(\mathrm{Km})$ & 24.2 & $(\mathrm{~N}=394)$ & 19.0 & $(\mathrm{~N}=734)$ \\
Walking Distance to Road $(\mathrm{Km})$ & 5.3 & $(\mathrm{~N}=214)$ & 2.6 & $(\mathrm{~N}=357)$ \\
Distance by Canoe to Market $(\mathrm{Km})$ & 34.1 & $(\mathrm{~N}=35)$ & 18.7 & $(\mathrm{~N}=30)$ \\
\hline \hline
\end{tabular}

households plus new in-migrants arriving, who are certainly younger than the 1990 heads who are now nine years older.

There is also an improvement in the education level of the population: the percentage of the population above age 6 in 1990 with at least complete primary education is over half, compared to $44 \%$ in 1990 , and the percentage with any secondary education was $19 \%$ in 1999 against $12 \%$ in 1990 . This increase reflects the increasing availability and accessibility of schools due to both school and road construction in communities in the northern Amazon during the 1990s.

Table 8 shows a small decrease in the sex ratio, representing a greater balance in the proportions of men and women. This tends to occur over time in frontier areas in the Amazon and elsewhere, as family members join the males who often arrive first. In northern Mato Grosso, Brazil, for example, the existence of forms of land use in addition to agriculture, such as mining, logging and large-scale cattle ranching, led initially to a situation of mainly male labor in new areas of settlement, which also occurred in Rondônia (Sydenstricker, 1993). In contrast, in Ecuador it has been rare for males to move to the region first to live alone, only to later be joined by their families: Although males often made a visit to the region to assess the situation prior to the move, once the move was decided upon, the whole family moved together (Bilsborrow, 2002).

Table 8 also shows the agro-ecological place of birth of heads of household in 1990 and 1999. In 1990, only 6\% of household heads in the rural sample had been born in the Ecuadorian Amazon, while by 1999 this rose to 13\%, mainly resulting from children of migrants aging to become heads of families themselves. There was also a small fall in the dominance of the Sierra or highlands relative to Coastal Ecuador as the place of birth. But as noted earlier in Table 1 , it is important to distinguish two groups of owners in 1999 , (1) those who were already there in 1990, and (2) the new heads, comprising both offspring of settlers and new in-migrants. Most new heads of household since 1990 , managing new farm units, are in fact migrants themselves: $88 \%$ of the recent owners migrated into the region. This would also suggest, as noted in Bilsborrow (2002), that population change is still being controlled primarily by migration rather than natural population growth. Thus, recent owners hailing from the Amazon region are primarily second-generation settlers (i.e., children of migrant farmers inheriting part of their parent's farm). However, this does not mean than new in-migrants are dominating the process since some of the recent owners are sons of heads who were themselves also born in areas of origin and came with their parents as migrants. For example, suppose a son was born in 1974 in the Sierra province of Loja, the family migrated to the Amazon in 1980, and the father gave the son 10 ha to farm as his own in 1998 (when the son was 24 ). That son would then still 


\section{ACTA AMAZONICA}

appear as a migrant head in terms of place of birth (even though he did not make the migration decision), although he is not a recent migrant.

A very important determinant of demographic change is the level of fertility. High fertility contributes to population growth, which may be a powerful driver of deforestation, to the extent the next generation remains in the Amazon region, particularly as new agricultural households. This would lead to additional demographic pressures on the land and thereby reductions in forest cover even if new in-migration to the region ceased (Bilsborrow, 2002). On the other hand, to the extent the children of existing setter couples tend to leave their parental farm and also leave the rural Amazon, the impact of high fertility on forest clearing would be less.

Table 9 provides preliminary estimates of fertility from the two surveys in 1990 and 1999, based on data on children ever born (CEB) for all women of childbearing. Overall, it appears that there has been a considerable decrease in fertility during the 1990s, following probably high and constant fertility in the previous decades. However, fertility seems to have risen slightly for younger women (aged 12-24), while for older women (30-49) the mean CEB decreased significantly from 1990 to 1999 . This may indicate that younger women are completing their desired family size at younger ages, and reducing childbearing at older ages.

Earlier, Thapa \& Bilsborrow (1995) used the 1990 data to analyze the fertility of settler wives (the spouses of the heads of household) and explored possible changes in fertility over time prior to 1990. They found mean number children ever born of these currently married women (almost all with large plots of land) to be 2.9 in 1990 , or higher than that of Ecuador as a whole (2.4) or of rural Ecuador (CEPAR, 1990). Also, CEB was found to vary greatly with education in 1990: Better educated frontier women had a significantly lower total fertility rate (mean of 3.2 for women with any secondary education) than women with no education (TFR of 8.2) - even larger than the same differentials at the national level of 2.9 vs. 6.3.

The total fertility rate (TFR) of married settler women was found to be very high in 1990, over 7 births per woman (Thapa \& Bilsborrow, 1995). Similar estimates for 1999 yield a TFR of 5.0. Both estimates may be somewhat distorted to the extent that fertility was years old. not constant in the years prior to the surveys, which is being further examined, but it seems that fertility has been declining. The results for 1999 may be compared with those from the latest National Demographic and Health Survey, also carried out in 1999: ENDEMAIN III (CEPAR, 2000) yielded a TFR of 5.5 for the Amazon region as a whole (urban and rural together, separate estimates not available), and with a TFR of 3.4 for the country as a whole (4.4 rural, 2.8 urban). As a contrast, the North region of Brazil (which contains the vast majority of the Amazon territory in the country) presented a TFR of 3.16 in 2000, according to the Brazilian Census (see http://www.ibge.gov.br).ENDEMAIN III was the first national demographic survey to include the Amazon region.

\section{CONCLUSIONS}

This paper summarizes data collection procedures and provides preliminary results for a unique longitudinal survey of migrant settler plots and the households found on those plots in the northern Ecuadorian Amazon. The data collected are from a representative probability sample of migrant settler colonist plots in the northern Ecuadorian Amazon, a region of

Table 8 - Comparison of Selected Demographic Characteristics in the Northern Ecuadorian Amazon, 1990 and 1999

\begin{tabular}{lcc}
\hline \hline Indicators & 1990 & 1999 \\
\hline Population (N) & 2,761 & $3,835 a$ \\
\hline Average Household Size & 6.6 & 5.9 \\
\hline Age Groups (\%) & & \\
\hline Until 12 & 40.6 & 40.4 \\
\hline 13 to 64 & 55.9 & 56.9 \\
\hline Above 65 & 3.5 & 2.7 \\
\hline Dependency Ratio b & 0.79 & 0.76 \\
\hline Mean Age / Head of Household & 44 & 43 \\
\hline Mean Age / Spouse of the Head & 39 & 37 \\
\hline Sex Ratio c & 1.2 & 1.2 \\
\hline Education (\%) & & 6.5 \\
\hline None & 7.2 & 41.0 \\
\hline Incomplete Primary & 48.4 & 33.7 \\
\hline Complete Primary & 32.6 & 14.3 \\
\hline Incomplete Secondary & 8.4 & 4.6 \\
\hline Complete Secondary or Higher & 3.4 & 20 \\
\hline Birth Origin of Household Head \% & & 68 \\
\hline Coast & 19 & 4 \\
\hline Highlands/Sierra & 75 & 9 \\
\hline Southern Amazon and Colombia & 2 & \\
\hline Study Area & 4 & \\
\hline \hline
\end{tabular}

a : not including 111 solares

b : proportion of population with below 15 and over 65 years old to the population between 15 and 64

$c$ : proportion of men in relation to women 


\section{ACTA \\ AMAZONICA}

CHANGES IN POPULATION AND LAND USE

OVER TIME IN THE ECUADORIAN AMAZON
Table 9-Comparison of Children Ever Born (CEB), by Age Group, and Total Fertility Rates (TFR), Northern Ecuadorian Amazon, 1990 and 1999

\begin{tabular}{lll}
\hline \hline Mean CEB a & 1990 & 1999 \\
\hline 12 to 14 & 0.01 & 0.03 \\
15 to 19 & 0.27 & 0.39 \\
20 to 24 & 1.37 & 1.61 \\
25 to 29 & 3.08 & 3.03 \\
30 to 34 & 4.51 & 4.16 \\
35 to 39 & 6.01 & 5.27 \\
40 to 44 & 8.80 & 6.54 \\
45 to 49 & 8.97 & 7.42 \\
\hline Total & 2.93 & 2.67 \\
\hline \hline
\end{tabular}

extraordinary biodiversity undergoing rapid deforestation. Households were visited in 1990 and 1999 in this region which experienced the most rapid rates of agricultural colonization in Ecuador over the past three decades, following the discovery of petroleum in 1967. We provide data on key demographic and socio-economic characteristics of the settler families, and on levels and trends in land cover and land use. The text discusses some possible linkages between the former and the latter, that is, on factors that may affect trends in land use and land cover change at the household level. The results we present show that high fertility and trends in family size, continuing migration into the region, aging of household members and the family life cycle, population density on the farm, and changes in the population composition by age/sex affect processes of land fragmentation, intensification and extensification in the Ecuadorian Amazon.

Population growth from both high fertility and inmigration has led to increasing subdivision and fragmentation of settler plots. This in turn has altered the usual change in land use over time in frontier regions, in which farmers replace crops with pasture for raising cattle. Nevertheless, it has not reduced deforestation, which is ongoing due to fragmentation of plots, and continuing to result in great ecological loss.

Our results provide substantial information about the process of colonization by migrant colonists, deforestation, and patterns of intensification and extensification over the period 1900-1999, which constitute an important instrument to understand recent changes in land use and population in the Amazon. These processes have, in fact, important implications for not only the Ecuadorian Amazon but also other Amazonian countries. In addition to a continuing conversion of forests to agriculture, there appear to be trends from more extensive to more intensive forms of land use (from pasture to perennials and annual crops, from perennials to annuals, from annuals which require less labor to those that use more, from longer to shorter fallow periods, and from less to more use of modern inputs (fertilizer, herbicides or pesticides). We have found some documentation for all of these trends in this paper, but it is important to understand these processes better. Thus it would be useful to know which processes are most important, which farmers in which areas are engaging in each process of intensification, and to what extent trade-offs exist between intensification and extensification. The latter is a key issue as evidence of a tradeoff would suggest that increasing intensification could alleviate pressures on further deforestation. This would make it possible to identify policies that could further this process.

This paper also illustrates the value of longitudinal or panel data. Panel data make possible analyses of trends and of the determinants of those trends, which is more useful than studies based only on a single round survey. Apart from being useful in the assessment of trends in extensification and intensification, panel data are useful in appraising trends in policies and their effects on changing behavior over time, which is important to determine for future policy formulation. For example, in the Ecuadorian Amazon study, data were collected on credit and technical assistance received by farm households in both the 1990 and 1999 surveys, including the type of assistance and the year. Analysis based on the 1990 data found little relationship between having received such assistance and settler land use or settler welfare, as based on annual farm household income or various measures of wealth (Murphy et $a l, 1997)$. But in fact the benefits of such assistance may be lagged. Thus in 1999, in contrast to 1990 , preliminary work suggests that credit availability has a strong association with both (increasing) deforestation and (altering) patterns of land use, primarily through increasing the area in pasture and raising cattle (Pan et al, 2001). The availability of panel data makes possible identifying whether and what types of assistance are associated with positive benefits for farmers, which would be useful policy implications. Indeed, the evaluation of the effects of any policy, or policy change, is far more feasible and valid with longitudinal data than a single cross-section of data.

We hope that other field studies in the Amazon that have collected data through a household survey aspire to collect data on the same households as plots of land in the future, to permit undertaking analyses that provide more valid inferences about the relationships between variables over time, which is fundamental to developing better policies.

\section{ACKNOWLEDGEMENTS}

This work is based on a project of the Carolina Population Center (CPC), Department of Geography, and Department of Biostatistics at the University of North Carolina in Chapel Hill, in collaboration with EcoCiencia, a leading non-profit ecological research organization in Quito, Ecuador (Richard E. Bilsborrow and Stephen J. Walsh Principal Investigators). We are grateful to the US National Aeronautics and Space Administration (NASA) (NCC5-295) and the Mellon Foundation for supporting all aspects of the project, and to the Summit and Compton Foundations and PROFORS (Proyecto Forestal, in Lago Agrio, Ecuador, funded by GTZ, the German 


\section{ACTA AMAZONICA}

foreign aid program) for helping support the household survey data collection in the Ecuadorian Amazon in 1999. In addition, NASA provided assistance with access to Landsat satellite imagery, the CPC Spatial Analysis Unit and the Department of Geography's Landscape Characterization \& Spatial Analysis Lab supported spatial and biophysical data collection and processing of remote sensing and GIS data, and the Centro de Estudios de Poblacion y Desarrollo Social (CEPAR) in Quito processed the 1999 household survey and the 2000 community survey data. These data have been further processed and analyzed at CPC with the assistance of graduate students supported by traineeships funded by the National Institute for Child Health and Human Development (HD07168) and other sources. Data from the earlier 1990 survey of Amazon household plots were collected and processed with funding provided by the US National Science Foundation, the World Wildlife Fund, and the CPC, with logistical support from Ecuadorian government agencies, including IERAC (the former Institute of Agrarian Reform and Colonization), CONADE (the former National Planning Agency), the Ministry of Agriculture and Cattle, and INIAP (the National Institute for Agricultural Research, in Coca).

\section{LITERATURE CITED}

Almeida, A. 1990. The colonization of the Amazon. University of Texas Press. Austin, Texas, 371p.

Bilsborrow, R. E. 2002. Population and land use in the Ecuadorian Amazon: proximate and underlying linkages. FAO monograph, 61p.

Bilsborrow, R.E.; Carr, D.L. 2001. Population, agricultural land use and the environment in developing countries. In: Lee, D.; Barrett, C. (Eds). Tradeoffs or Synergies? Agricultural Intensification, Economic Development and the Environment. CAB International. Wallingford, UK. p. 35-55.

CEPAR. 1990. Ecuador: Encuesta Demografica y de Salud Familiar 1989. CEPAR (Centro de Estudios sobre Población y Desarrollo Social). Quito, Ecuador, 211p.

CEPAR. 2000. Encuesta demografica y de salud materna $e$ infantil. ENDEMAIN III. CEPAR (Centro de Estudios sobre Población y Desarrollo Social) and CDC (Centers for Disease Control). Quito, Ecuador, 242p.

DeWalt, B. 1985. Microcosmic and macrocosmic processes of agrarian change in Southern Honduras: the cattle are eating the forest. In: DeWalt, B.; Pelto, P. (Eds). Micro and Macro Levels of Analysis in Anthropology: Issues in Theory and Research. Westview Press. Boulder, Colorado, 165-186.

FAO - United Nations Food and Agricultural Organization. 2001. State of the World's Forests, Department of Forestry. United Nations Secretariat. New York, NY, 154p.

Hecht, S. 1985. Environment, development, and politics: capital accumulation and the livestock sector in Eastern Amazonia. World Development, 13(6):663-684, 172p.
Heckandon, S. 1983. Cuando se acaban los montes. Impretex S.A. (para Smithsonian Tropical Research Institute). Panana City.

INEC. 1992. V censo de población y IV de vivienda; resultados definitivos. INEC (Instituto Nacional de Estadistica y Censos). Quito, Ecuador, 86p.

INEC. 2001. VI censo de población y V censo de vivienda, 2001: resultados preliminares. INEC (Instituto Nacional de Estadistica y Censos). Quito, Ecuador, 91p.

Kaimowitz, D. 1997. Factors determining low deforestation: The Bolivian Amazon. Ambio, 26(8): 537-540.

Marquette, C. 1998. Land use patterns among small farmer settlers in the Northern Ecuadorian Amazon. Human Ecology, 26(4): 573-598.

Murphy, L.; Bilsborrow, R.; Pichón, F. 1997. Poverty and prosperity among migrant settlers in the Amazon Rainforest Frontier of Ecuador. Journal of Development Studies, 34(2):35-65.

Myers, N.; Mittermeier, R.; Mittermeier, C.; Fonseca, G.; Kents, J. 2000. Biodiversity hotspots for conservation priorities. Nature, 403: 853-858.

Pan, W., L. Murphy, B. Sullivan; R. E. Bilsborrow. 2001. Population and Land Use in Ecuador's Northern Amazon in 1999: Intensification and Growth in the Frontier. Meeting of the Population of America Association, Washington, D.C., 27p

Pichón, F.J. 1993. Agricultural settlement, land use, and deforestation in the Ecuadorian Amazon Frontier: a microlevel analysis of colonists' land-allocation behavior. Doctoral Dissertation, University of North Carolina, Chapel Hill, 291p.

Pichón, F.J. 1997. Colonist land-allocation decisions, land use, and deforestation in the Ecuadorian Amazon Frontier. Economic Development and Cultural Change 45(4): 707-744.

Pichón, F.; Bilsborrow, R.E. 1999. Land-use systems, deforestation and associated demographic factors in the humid tropics: farmlevel evidence from Ecuador. In: Bilsborrow, R.E.; Hogan, D. (Eds). Population and Deforestation in the Humid Tropics. IUSSP. Liege, Belgium, 175-207.

Rudel, T. 1983. Roads, speculators, and colonization in the Ecuadorian Amazon. Human Ecology 11: 385-403.

Southgate, D.; Sierra, R.; Brown, L. 1991. The causes of tropical deforestation in Ecuador: A statistical analysis. World Development, 19(9): 1145-1151.

Sydenstricker, J. 1993. Household size, sex composition, and land use in tropic moist forests: evidences from the Machadinho Colonization Project, Rondônia, Brazil. Annual Meeting of Population Association of America, Cincinnati, Ohio, April, 1993, 20p.

Thapa, K.; Bilsborrow, R. 1995. Fertility in the Ecuadorian Amazon. Carolina Population Center (unpublished), Chapel Hill, NC, USA.

Vallejo, L.; Bilsborrow, R. 2001. Proceso de desarrollo urbano en la Amazonia Ecuatoriana. Quito, CEPAR, unpublished.

\section{RECEBIDO EM: 09/02/04 \\ ACEITO EM 16/09/04}


